\title{
Translocation and hand-rearing techniques for establishing a colony of threatened albatross
}

\author{
TOMOHIRO DEGUCHI, JUDY JACOBS, TOMOKO HARADA, \\ LYNDON PERRIMAN, YUKI WATANABE, FUMIO SATO, \\ NOBORU NAKAMURA, KIYOAKI OZAKI and GREG BALOGH
}

\section{Summary}

Many breeding colonies of Procellariiformes have been threatened with extinction. Chick translocation has been shown to be an effective method for establishing new "safer" colonies of burrow-nesting species, but techniques for surface-nesting species have not been fully developed. The entire breeding population of the threatened Short-tailed Albatross Phoebastoria albatrus is restricted to two sites, Torishima Island and the Senkaku Islands, and neither site is secure due to volcanic activity or political instability. The Short-tailed Albatross Recovery Team has recommended facilitating the recovery of this species by establishing at least one additional colony through the translocation and hand-rearing of chicks at a safe historical breeding site. To evaluate the feasibility of this approach, we hand-reared 1o post-guard phase chicks of two related species in 2006-2007: Laysan Albatross P. immutabilis translocated from Midway Atoll to Kaua'i Island, Hawai'i and Black-footed Albatross P. nigripes translocated from a nearby islet in the Ogasawara (Bonin) Islands to Mukojima Island, Japan. In these pilot studies, 40\% of Laysan Albatross chicks and $90 \%$ of Black-footed Albatross chicks fledged successfully. Following this groundwork, 40 post-guard phase Short-tailed Albatross chicks were translocated from Torishima Island to Mukojima Island in February 2008-2010 and hand-reared to fledging. Their fledging success has been $100 \%$ in all three years. Fledging body sizes were similar or greater in hand-reared chicks at the release site than parent-reared chicks on Torishima Island. There were significant differences in levels of some blood chemistry parameters between pre-fledging hand-reared and parent-reared chicks. The techniques developed in our studies have broad-reaching implications for the future conservation of threatened populations of other surface-nesting seabirds.

\section{Introduction}

Many breeding colonies of Procellariiformes have been threatened with extinction by the introduction of non-native predators, anthropogenic impacts, sea-level rise caused by global warming, and/or natural disasters (Meyer et al. 2000, Baker et al. 2002, 2006, de Villiers et al. 2005, Hilton and Cuthbert 2010, Croxall et al. 2011, Madeiros et al. 2011). There is therefore an urgent need to restore or establish new colonies of these species at safer sites. Chick translocation is one effective method for establishing new colonies of these highly philopatric seabirds (Priddel et al. 2006, Miskelly et al. 2009, Carlile et al. 2011). Techniques for translocation and handrearing of chicks have been developed only for burrow-nesting species that imprint on their natal site later in development, immediately after emerging from the burrow (reviewed in Gummer 2003, Miskelly et al. 2009).

In contrast, translocation and hand-rearing techniques have not been well developed for surface-nesting species. The available information indicates that surface-nesting species imprint on their natal site earlier in development and need to be translocated at a much younger stage 
(Fisher 1971). For example, Fisher (1971) demonstrated that 35\% of Laysan Albatross Phoebastria immutabilis chicks translocated $5 \mathrm{~km}$ from the natal site at 3-4 four weeks of age, and successfully reared by surrogate parents, returned to their relocation site after four years. In contrast, only $5 \%$ of chicks that were translocated at 5.5 months of age and successfully fledged returned to their relocation site after four years. Robertson and Wright (1973) detailed the supplementary feeding of an abandoned northern Royal Albatross Diomedea sanfordi chick at Taiaroa Head on the South Island of New Zealand. The chick was fed halibut oil, octopus and squid, and survived to later return and breed successfully at this site (L. Perriman unpubl. data).

Historically, breeding colonies of Short-tailed Albatross Phoebastria albatrus were broadly distributed in the north-western Pacific islands. The species was driven to the brink of extinction by feather hunters, who harvested hundreds of thousands of birds per year, and by destruction of breeding habitat by guano diggers during 1886-1939 (Yamashina 1942, Hasegawa 2003). By 1949, there were no Short-tailed Albatrosses breeding at any of the historically known breeding sites, and the species was thought to be extinct (Austin 1949). A few breeding Short-tailed Albatrosses were rediscovered on Torishima Island $\left(30^{\circ} 29^{\prime} \mathrm{N}, 140^{\circ} 18^{\prime} \mathrm{E}\right)$ in 1950 and on the Senkaku Islands ( $25^{\circ} 47^{\prime} \mathrm{N}, 124^{\circ} 03^{\prime} \mathrm{E}$ ) in 1971 (Yamamoto 1954, Hasegawa 2003). Since then, the population at these two sites has increased at an estimated rate of $6-8 \%$ per year (Hasegawa 2007). In 2008, the population was estimated to be about 2,400 individuals with $80-85 \%$ of all birds breeding on Torishima Island (USFWS 2008).

The increase in numbers of breeding Short-tailed Albatross results partly from legal protection and habitat management by Japanese scientists and government departments. The increasing population trend is an encouraging signal for the recovery of this species. However, it is still considered endangered by the U.S. and Japanese governments and listed as 'Vulnerable' by IUCN. Although this species faces a variety of threats including breeding habitat loss, severe weather and bycatch in commercial fisheries, perhaps the most significant threat is the instability of the two breeding islands. No researcher is allowed to land on the Senkaku Islands as they are disputed territory between Japan, Taiwan and China (USFWS 2008). Torishima Island is an active volcano that has erupted four times in the past 100 years (Torishima Society 1967), most recently in 2002. Moreover, the main Short-tailed Albatross breeding colony on Torishima Island is located on a steep and unstable alluvial outwash fan prone to landslides, the most recent of which buried at least 10 Short-tailed Albatross chicks on 18 February 2010 (F. Sato unpubl. data).

The goal of our project is to establish at least one additional breeding colony of Short-tailed Albatross on a safe, historical breeding site as prerequisite for the recovery of the species (Hasegawa 2003, USFWS 2008). Developing appropriate techniques for translocation and hand-rearing of chicks is necessary to achieve this goal. During pilot studies in 2006 and 2007, we developed these techniques using chicks of the two more abundant, smaller and more docile North Pacific albatross species, Laysan Albatross P. immutabilis and Black-footed Albatross P. nigripes. We subsequently applied these techniques to translocations of the threatened, larger and less docile Short-tailed Albatross during the following three years, 2008-2010. Here, we report on the successful techniques developed for translocating and hand-rearing chicks of the three albatross species. Throughout the study, we compared fledging success, change in body mass, fledging size and blood chemistry of translocated chicks to those of parent-reared chicks at the source colony.

\section{Methods}

\section{Translocation of chicks}

To ensure a higher probability of fidelity to the release site, based on the results of Fisher (1971), we decided to transfer albatross chicks at one month old, just at the post-guard stage when chicks are capable of thermoregulation (Tickell 2000, Gummer 2003).

Ten Laysan Albatross chicks approximately one month old with mean body mass \pm SD $1,180 \pm$ $350 \mathrm{~g}$, and later determined to be five females and five males (for details of age and sex 
determination see Appendix SI in the online Supplementary Materials) were randomly selected and captured on Sand Island $\left(28^{\circ} 12^{\prime} \mathrm{N}, 177^{\circ} 22^{\prime} \mathrm{W}\right)$ on Midway Atoll National Wildlife Refuge (NWR) on 3 March 2006. The 1o chicks were placed in individual open cardboard boxes $(30 \times 40 \times 30 \mathrm{~cm}$ ) lined with an absorbent sheet on the bottom (Harada et al. 2008). They were immediately transported by plane 2,00o km southeast to Lihue Airport, Kaua'i Island, Hawai'i (transport time: four hours). At the airport, a numbered plastic identification band (KPo68-KPo77) was placed on the left leg of each chick, and throat and cloacal swabs were collected to test for Newcastle disease and avian influenza. We then transported chicks by car to Kilauea Point NWR $\left(22^{\circ} 13^{\prime} \mathrm{N}, 159^{\circ} 24^{\prime} \mathrm{W}\right)$ and released them from the boxes into a garage for quarantine until laboratory results indicated that the chicks were free of tested diseases. On 8 March 2006, the chicks were released at Crater Hill (c.170 m asl) on Kilauea Point NWR. They were placed 5-10 m apart on flat ground devoid of natural nest depressions.

On 20 March 2007, 10 Black-footed Albatross chicks approximately 50 days old (mean body mass \pm SD: $2,633 \pm 258 \mathrm{~g}$, later determined to be four females and six males) were randomly selected and captured on the western part of Nakodojima Island $\left(27^{\circ} 38^{\prime} \mathrm{N}, 142^{\circ} 10^{\prime} \mathrm{E}\right.$, Figure 1$)$. Chicks were placed in individual open corrugated plastic boxes $(50 \times 50 \times 70 \mathrm{~cm})$ lined with an absorbent sheet on the bottom. They were transported via a fishing boat $5 \mathrm{~km}$ north to a beach adjacent to the release site (Figure $1,2 \mathrm{a})$ on Mukojima Island $\left(27^{\circ} 41^{\prime} \mathrm{N}, 142^{\circ} \mathrm{O} 7^{\prime} \mathrm{E}\right.$, transport time: $40 \mathrm{~min}$ ). Half of these chicks (two females and three males) were immediately carried to the release site, a level, grassy plateau above this beach. They were removed from their boxes and placed 5-10 m apart on flat ground devoid of natural nest depressions (immediate-release group, total transit time: three hours). The remaining five chicks (two females and three males) were kept in the boxes on the boat, and transported for five hours around Mukojima Island, to study

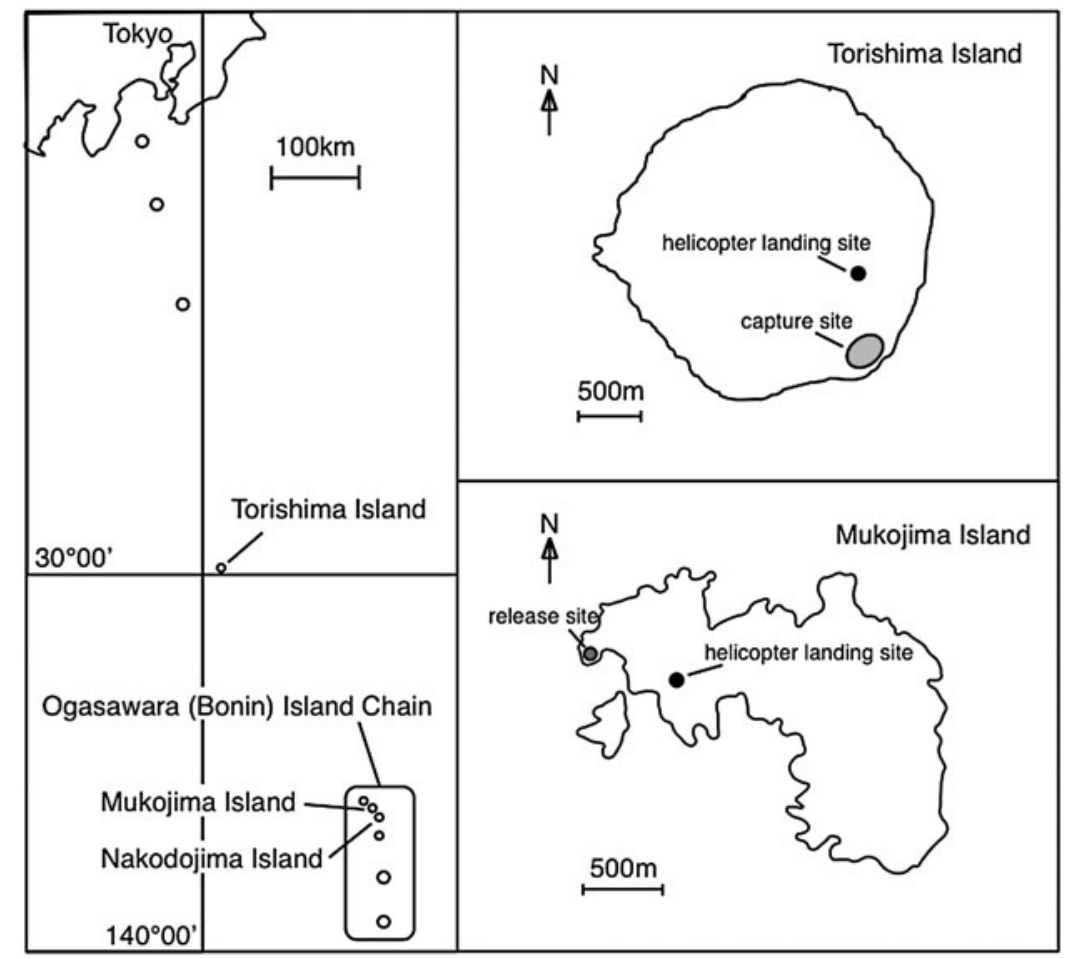

Figure 1. Locations of study sites. 


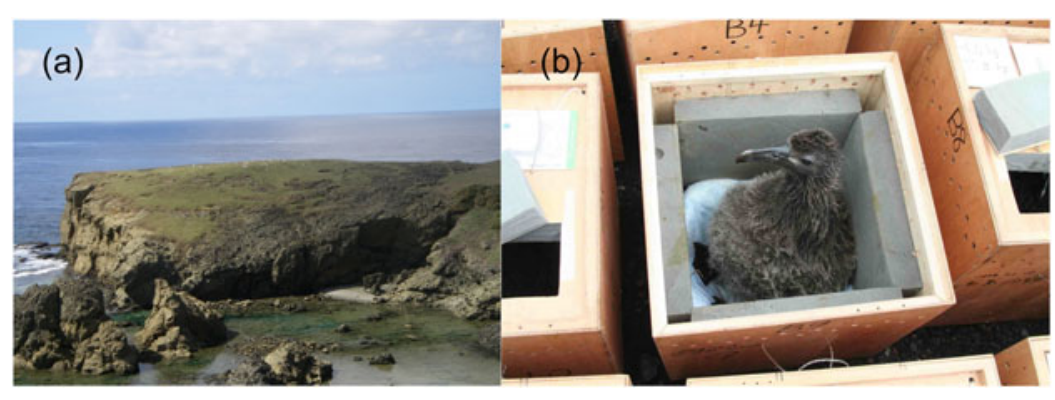

Figure 2. (a) The release site on a headland on the west end of Mukojima Island where Blackfooted and Short-tailed Albatross chicks were hand-reared in 2007-2010. (b) Short-tailed Albatross chick placed in a ventilated and temperature-monitored wooden box with sides lined with sponges and an absorbent sheet on the bottom.

the effect of a long boat transport time, with rocking motion, on their survival and growth (anticipating the possibility that Short-tailed Albatross chicks might be transported by boat). They were placed 5-10 $\mathrm{m}$ apart on the same site the as immediate-release group the next morning, 20 hours after their capture (delayed-release group). A numbered plastic identification band (M400-M409) was placed on the left leg of each chick on the release day. Scheduling of Black-footed Albatross chick translocation was adjusted according to weather forecasts for the source colony and release site.

In September 2007, the release site on Mukojima was prepared to increase suitability and site fidelity for Short-tailed Albatross chicks, by scattering 30 Short-tailed Albatross decoys and nine artificial Short-tailed Albatross eggs throughout the site (Figure 2a). In February 2009, we deployed a solar-powered playback unit, which continuously played Short-tailed Albatross courtship calls and colony sounds from the main colony on Torishima Island from two 6o-watt directional and two 20-watt omni-directional speakers during the daylight hours from November to May. We could detect these recordings as far as $500 \mathrm{~m}$ offshore.

On 19 February 2008, 10 Short-tailed Albatross chicks (later determined to be six female and four male), approximately 40 days old were captured and translocated from the main colony on the alluvial outwash fan on Torishima Island (Figure 1) to Mukojima Island. Following our 2008 Short-tailed Albatross work, we considered 15 chicks per year was a feasible number of translocated individuals to manage. Therefore, the process was repeated on 5 February 2009 with five females and 1o males, approximately 33 days old, and on 8 February 2010 with four females and 11 males, approximately 35 days old. Different nests at Torishima Island were selected each year to prevent individual pairs experiencing apparent breeding failure more than once. Mean body mass \pm SD of chicks transferred in 2008, 2009 and 2010 was 4,450 $\pm 481 \mathrm{~g}, 3,667 \pm 328 \mathrm{~g}$ and $3,987 \pm 472 \mathrm{~g}$, respectively. The chicks were placed in individual ventilated wooden boxes $(40 \times 40 \times 50 \mathrm{~cm})$ with sides lined with sponges against shock to prevent injury during transit and an absorbent sheet on the bottom (Figure $2 \mathrm{~b}$ ). Box lids were fitted with thermometers to monitor internal box temperature. We opened the ventilation hatch when the internal box temperature exceeded $35^{\circ} \mathrm{C}$. Based on the results of Black-footed Albatross translocation, we decided to transport Short-tailed Albatross chicks by helicopter rather than by boat, despite the additional cost. To reduce the risk of helicopter/albatross collisions on Torishima Island, the boxes were carried by field personnel to the top of the 120-m high alluvial outwash fan, where they were loaded onto a helicopter and transported for 90 minutes $(350 \mathrm{~km})$ south to Mukojima Island. Upon arrival at the helicopter landing site, chicks were carried $\mathrm{I} \mathrm{km}$ to the same release site as Black-footed Albatross translocation study. As before, we removed chicks from their boxes and placed them 5-10 m apart on flat ground devoid of natural nest depressions. Total transit time 
was 6-8 hours. On the day following release, a numbered plastic identification band (Yo1-Y44) was placed on the left leg of each chick. Scheduling of Short-tailed Albatross chick translocations was also adjusted according to weather forecasts for the source colony and release site. For more details see Appendix $\mathrm{S}_{1}$ in the online Supplementary Materials.

\section{Chick growth and confirmation of fledging}

The hand-reared Laysan Albatross chicks were placed in a nylon bag and weighed daily, to the nearest $10 \mathrm{~g}$, using a spring scale. To minimise handling disturbance, Black-footed Albatross and Short-tailed Albatross chicks were placed in a basket and weighed only every five days, using a digital hanging scale (to the nearest $1 \mathrm{~g}$ ). The last recorded mass of chicks within five days of leaving the colony was used as the fledging mass. To compare change in mass between parentreared and hand-reared chicks, we used the values of parent-reared Laysan Albatross from Fisher (1967) and weighed 16 parent-reared Black-footed Albatross chicks (11 females, four males and one unknown) on Mukojima every five days during the study period in 2007. Growth curves of parent-reared Short-tailed Albatross chicks were derived from a long-term dataset of chick measurements taken on Torishima Island at eight periods during development $(n=24-102$ chicks per period) in February-May 1982-2008 (H. Hasegawa and Yamashina Institute for Ornithology unpubl. data). Measurements taken on Torishima Island on 18-19 April and 23-25 May in these years were considered to be peak and fledging mass, respectively. Body mass of parent-reared Short-tailed Albatross chicks measured before and after mid-April was fitted to a Gompertz curve and cubic regression, respectively.

Rate of increase in mass was calculated by fitting a Gompertz curve between initial mass and peak mass using the mass gained, divided by the time required for growth between $10 \%$ and $90 \%$ of the asymptote, as described by Ricklefs (1968). Hatchling mass of Laysan Albatross (190 g) and Black-footed Albatross (209 g) required for curve fitting was derived from Whittow (1993a, 1993b). Short-tailed Albatross hatchling mass ( $272 \mathrm{~g}$ ) was estimated by egg mass ( $380 \mathrm{o}$; Watabe 1963) multiplied by hatchling/egg mass ratio (0.72) of other albatross species (Marchant and Higgins 1990, Whittow 1993a, 1993b, Tickell 2000).

We measured the exposed culmen and tarsus lengths using a calliper (to the nearest $0.1 \mathrm{~mm}$ ), and wing lengths using a ruler (to the nearest $1 \mathrm{~mm})$ in parent-reared $(n=13)$ and hand-reared Black-footed Albatross chicks in 2007 and hand-reared Short-tailed Albatross chicks in 20082010 within 1o days of fledging. These measurements were taken on parent-reared Short-tailed Albatross chicks $(n=24)$ on Torishima Island on 23-25 May 2008. These pre-fledging measurements were used to compare fledging size between parent-reared and hand-reared chicks using a $t$-test assuming that there is a little inter-annual variation in the measurements of parentreared chicks.

As hand-reared chicks neared fledging age, we checked for departures and observed behaviour before and after fledging from at least $50 \mathrm{~m}$ away every morning. There were no predators at the release site, so missing chicks were assumed to have fledged. Hand-reared Black-footed Albatross and Short-tailed Albatross fledglings (identity confirmed by observation of leg bands) were often seen at sea near the shoreline of Mukojima Island during the days immediately post-fledging.

\section{Blood chemistry}

We sampled blood from both parent-reared and hand-reared chicks to monitor and compare their physiological health. Whole blood samples (100 $\mu \mathrm{l}$ ) were taken from the tarsus vein of 26 handreared Short-tailed Albatross chicks on 10 May 2008 ( $n=10$ chicks), 11 May 2009 ( $n=7$ chicks) and 12 May 2010 ( $n=9$ chicks), and from 30 parent-reared chicks on 23-25 May 2008 on Torishima Island. We measured the concentrations of 12 plasma biochemical parameters (sodium, potassium, calcium, phosphorus, aspartate aminotransferase, creatine kinase, bile acid, uric acid, 
total protein, albumin, globulin, glucose) using blood biochemical analyzer (VetScan $\mathrm{VS}_{2}{ }^{\mathrm{TM}}$ ) and reagent kit (Avian/Reptilian Profile Plus ${ }^{\mathrm{TM}}$ ). Potassium and glucose concentrations are strongly correlated with the time lapse between sample acquisition and analysis (Nanji 1984). In our study, we could not statistically compare these parameters between parent-reared and hand-reared Short-tailed Albatross chicks because of unequal time between sample collection and processing at the source colony vs. release site. We combined all three years of biochemical data for handreared chicks and compared them to parent-reared chicks using the Mann-Whitney U-test because these data were not normally distributed.

\section{Diet and hand-feeding of chicks}

For details see Appendix $\mathrm{S}_{\boldsymbol{I}}$ in the online Supplementary Materials.

\section{Results}

\section{Fledging successes}

Fledging success of Laysan Albatross chicks hand-reared in the first pilot study was $40 \%$. Three translocated Laysan Albatross chicks (two females and one male) died within one month of the relocation from exposure during unseasonably rainy weather (number of rainy days and rainfall amount on north shore of Kaua'i Island in March 2006: 23 days and 577.9 mm; Weather Underground 2010). Two additional male chicks died just before fledging in July. Necropsy at U.S. Geological Survey National Wildlife Health Center Honolulu Field Station indicated massive bacterial infections in the gastro-intestinal tracts of these birds. Another female chick sustained an injury to ligaments of the left carpal joint, possibly associated with daily handling for weighing, and could not fly. This Laysan Albatross now resides at the Monterey Bay Aquarium, California. The remaining four chicks fledged between 7 and 18 July 2006.

Fledging success of Black-footed Albatross chicks hand-reared in the second pilot study was $90 \%$. Two weeks after the translocation, one female Black-footed Albatross chick in the delayed-release group suddenly became incapacitated and died in a prone position the following morning. Necropsy at the veterinary laboratory, Gifu University, Japan revealed that the direct cause of death was most likely suffocation; the trachea was filled with regurgitation. Some calcified fecal impactions were found but there was no symptom of bacterial infection in the intestine. From the chick's appearance just before death, we concluded that this chick was probably unable to stand due to food retention and its prone posture caused suffocation during incomplete regurgitation. The remaining nine handreared chicks fledged between 24 May and 14 June 2007. There were no significant differences in fledging success $\left(\chi_{1}^{2}<0.01, P>0.99\right)$ and fledging date $\left(t_{20}=0.02, P=0.98\right)$ between parentreared (fledging success: $93 \%$, mean fledging date: 9 June) and hand-reared chicks (90\%, 9 June).

All hand-reared Short-tailed Albatross chicks successfully fledged between 11 and 29 May (mean fledging dates: 21 May in 2008, 19 May in 2009, 23 May in 2010). Most fledging occurred between o6hoo and oghoo. Chicks we observed fledging departed the top of the cliff at the edge of the hand-rearing site into a headwind and glided down to the sea surface. All chicks seemed healthy before fledging and the fledglings observed at sea displayed good water repellency. There were no significant differences $\left(\chi_{1}^{2}<0.01, P>0.99\right)$ in fledging success between parent-reared and hand-reared Short-tailed Albatross chicks (parent-reared chicks at stable ground on Torishima Island: 99\%, $n=189$ chicks, F. Sato and H. Hasegawa unpubl. 2001-2010 data).

\section{Chick growth}

Hand-reared Laysan Albatross chicks exhibited similar growth patterns to those reported for parent-reared chicks (Figure 3), and there were no significant differences in peak and fledging mass between parent-reared and hand-reared chicks (Table 1 ). 
There were no significant differences in rate of mass increase and peak mass between parentreared and hand-reared Black-footed Albatross chicks (Table 1 ) and both groups exhibited similar body mass gain for the first four weeks (Figure 4). However, more than one month prior to fledging, hand-reared chicks were 300-800 g heavier than parent-reared chicks. The apparent difference in growth pattern between groups was caused by variance in date of peak body mass of parent-reared chicks. There was no difference in peak mass between hand-reared and parentreared chicks (Table 1 ). Fledging mass was heavier in hand-reared than in parent-reared chicks (Table I) but there were no significant differences in fledging skeletal and wing lengths between groups (Table 2). Hand-reared chicks had slightly heavier body mass in immediate-release than in delayed-release group in the later period (Figure 4).

Hand-reared Short-tailed Albatross chicks decreased in body mass by $300 \mathrm{~g}$ soon after their translocation in all three years (Figure 5). Hand-reared chicks had a slower rate of increase in mass than parent-reared chicks in every year, but there were no significant differences in peak mass between two groups (Figure 5, Table 3). Hand-reared Short-tailed Albatross chicks in 2008 and 2010 had heavier fledging mass than parent-reared chicks (Table 3). There were no significant differences in culmen length at fledging, but hand-reared chicks did have longer tarsus lengths (2010 only) and wing lengths (all years) than parent-reared chicks (Table 3).

\section{Blood chemistry}

Hand-reared chicks showed lower levels of sodium and higher level of phosphorus, asparte aminotransferase (hereafter AST), creatine kinase (hereafter CK), uric acid and albumin than parent-reared chicks (Table 4 ). The level of bile acids in every sample was lower than measurement limit of our analyser $(<35 \mathrm{UMOL} / \mathrm{L})$.

\section{Habituation to hand-feeding}

Habituation to hand-feeding varied among species from slight in Laysan Albatross to none in Short-tailed Albatross. We had to force-feed Laysan Albatross chicks during the first two months, but later in development, some individuals did approach us and all chicks voluntarily took food from our hands. No Black-footed Albatross chicks approached us throughout hand-rearing, but

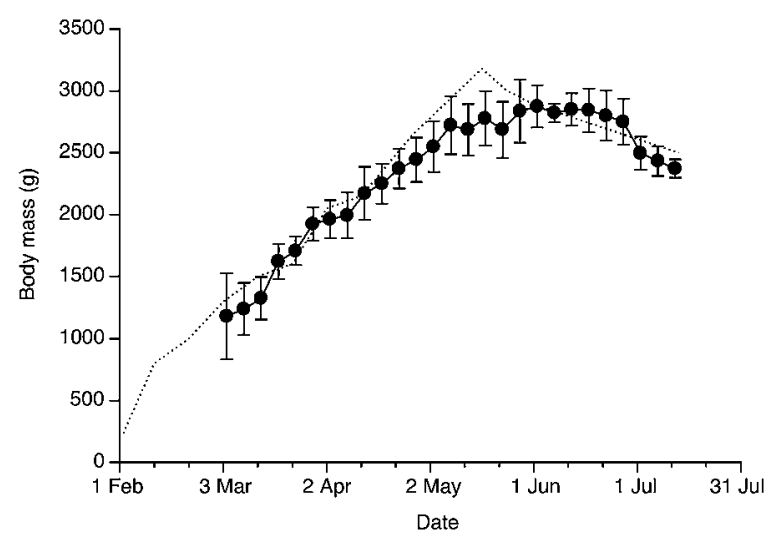

Figure 3. Body mass changes of hand-reared and parent-reared Laysan Albatross chicks. Solid circles and error bars show mean body mass \pm SD of hand-reared chicks $(n=4-10)$. Dashed line depicts mean body mass of parent-reared chick $(n=20-50)$ cited from Fisher (1967). 
Table 1. Changes in mass of parent-reared and hand-reared Laysan and Black-footed Albatross chicks. Parent-reared Laysan Albatross data are cited from Fisher (1967). Rate of mass increase was represented as mass gained divided by the time required for growth between 10\% and $90 \%$ of the asymptote according to Ricklefs (1968). Fledging mass of hand-reared Laysan Albatross and both groups of Black-footed Albatross are the last recorded mass within 5 days of chick departure. Means \pm SD (and sample size in parentheses) are presented.

\begin{tabular}{|c|c|c|c|c|c|c|}
\hline & \multicolumn{3}{|c|}{ Laysan Albatross chicks } & \multicolumn{3}{|c|}{ Black-footed Albatross chicks } \\
\hline & Parent-reared & Hand-reared & $t$-statistic & Parent-reared & Hand-reared & $t$-statistic \\
\hline $\begin{array}{c}\text { Rate of mass } \\
\text { increase } \\
\text { (g/day) }\end{array}$ & $27 \cdot 7^{\mathrm{a}}$ & $23.6 \pm 2.9(4)$ & - & $40.4 \pm 8.8\left(13^{b}\right)$ & $35.5 \pm 4.0(9)$ & 1.55 \\
\hline Peak mass (g) & $3180 \pm 595(50)$ & $3060 \pm 120(4)$ & 0.38 & $3676 \pm 402(15)$ & $3813 \pm 218(9)$ & 0.94 \\
\hline $\begin{array}{l}\text { Fledging } \\
\text { mass (g) }\end{array}$ & $2310 \pm 260(16)$ & $2340 \pm 80(4)$ & 0.20 & $2334 \pm 339\left(13^{c}\right)$ & $2954 \pm 253(9)$ & $4 \cdot 46^{* *}$ \\
\hline
\end{tabular}

${ }^{a}$ Standard deviation could not be represented because the growth rate was calculated from mean body mass shown in Fisher (1967).

'Two chicks' data were excluded because their body mass did not increase during the weighing period.

'Two chicks' data were excluded because they were not monitored to fledging.

$* * \mathrm{P}<0.01$ ( $t$-test).

some chicks voluntarily opened their mouths for food later in development. Two to three weeks before fledging, however, even Laysan Albatross and Black-footed Albatross resisted handling and feeding. Unlike Laysan Albatross and Black-footed Albatross chicks, hand-reared Short-tailed Albatross chicks never grew accustomed to being fed throughout the hand-rearing period. Early in the 2008 Short-tailed Albatross translocation effort, the chicks often regurgitated soon after being handled for hand-feeding. When feeding was restricted prior to fledging, we often observed some Short-tailed Albatross chicks exhibiting begging behavior to decoys, suggesting to us that they were firmly imprinted upon their own species, and not to humans.

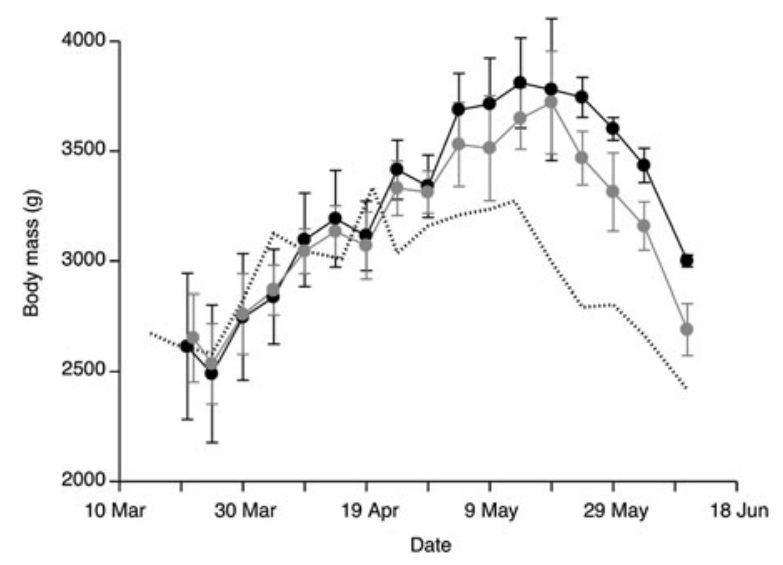

Figure 4. Body mass changes of hand-reared and parent-reared Black-footed Albatross chicks. Symbols with error bars show mean body mass \pm SD of hand-reared chicks in immediate-release group (black circles, $n=5$ ) and in delayed-release group (grey circles, $n=4-5$ ). Dashed line depicts mean body mass of parent-reared chicks $(n=15-16)$. 
Table 2. Fledging body sizes of parent-reared and hand-reared Black-footed Albatross chicks. Measurements of parent-reared and hand-reared chicks were conducted during 24 May-13 June and 14 May-13 June 2007, respectively. Means \pm SD (and sample size in parentheses) are presented.

\begin{tabular}{llcc}
\hline & Parent-reared & Hand-reared & $t$-statistic \\
\hline Exposed culmen length (mm) & $98.9 \pm 3.1(13)$ & $97.0 \pm 4.6(9)$ & 1.18 \\
Tarsus length (mm) & $92.7 \pm 3.2(13)$ & $91.5 \pm 3.3(9)$ & 0.85 \\
Wing length (mm) & $454 \pm 27(13)$ & $466 \pm 28(9)$ & 1.03 \\
\hline
\end{tabular}

\section{Discussion}

\section{Translocation techniques}

In the first pilot study, three Laysan Albatross chicks died within one month of translocation due to exposure during unseasonably rainy weather. Survival of chicks already stressed by transportation and hand-feeding might be strongly affected by local weather conditions. Body temperature of young Laysan Albatross chicks rapidly decreases when their down becomes wet (Howell and Bartholomew 1961) and cold stress suppresses the immune responses of birds (Regnier and Kelley 1981, Siegel 1985). It is important to consider the local weather conditions and chick sheltering options when determining the timing and location of chick translocation.

In the second pilot study, there was no notable difference in change in body mass between translocated Black-footed Albatross chicks in the immediate-release and delayed-release group. However, the one chick that died early in development was from the delayed-release group that was subjected to the potential stress associated with additional ship transport and holding time. In general, transport stress that adversely affects animal health increases with transportation time (Teixeira et al. 2007). We believe it was worth the additional expense of helicopter flight to minimise transport time for threatened Short-tailed Albatrosses.

Some hand-reared Short-tailed Albatross chicks that often regurgitated in 2008 were extremely wary of our approach when they were captured on Torishima Island, and their character did not change throughout the hand-rearing period, although the frequency of regurgitation decreased. In

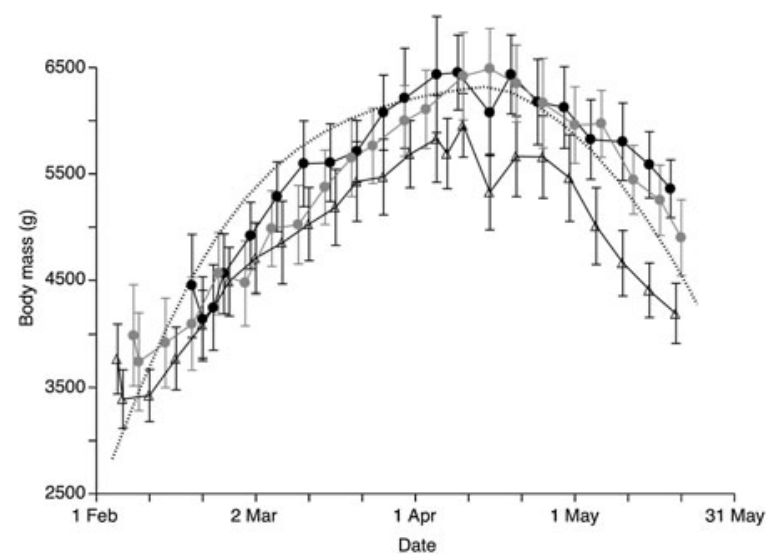

Figure 5. Body mass changes of hand-reared and parent-reared Short-tailed Albatross chicks. Symbols with error bars show mean body mass \pm SD of hand-reared chicks in 2008 (black circles), 2009 (triangles) and 2010 (grey circles). Dashed line depicts mean of parent-reared chick's body mass $(n=24-102)$ fitted to Gompertz curve by middle of April and subsequently fitted to cubic regression. 
Table 3. Change in mass and fledging sizes of parent-reared and hand-reared Short-tailed Albatross chicks. For rate of mass increase, see Table 1 . Body mass of parent-reared chicks measured on 18-19 April and 23-25 May were used as peak and fledging mass, respectively. Fledging body sizes of parent-reared chicks were measured on 23-25 May 2008 and those of hand-reared chicks were measured on 9-19 May 2008, 1-21 May 2009, 7-18 May 2010. Means \pm SD (and sample size in parentheses) are presented.

\begin{tabular}{|c|c|c|c|c|c|c|c|}
\hline & \multirow{2}{*}{$\begin{array}{l}\text { Parent-reared } \\
(\mathrm{PR})\end{array}$} & \multirow{2}{*}{$\begin{array}{l}\text { o8 hand-reared } \\
\text { (o8 HR) }\end{array}$} & \multirow{2}{*}{$\begin{array}{l}\text { og hand-reared } \\
\text { (o9 HR) }\end{array}$} & \multirow{2}{*}{$\begin{array}{l}\text { 1o hand-reared } \\
\text { (1o HR) }\end{array}$} & \multicolumn{3}{|c|}{$t$-statistic } \\
\hline & & & & & $\begin{array}{l}\text { PR vs } \\
\text { o8 HR }\end{array}$ & $\begin{array}{l}\text { PR vs } \\
\text { o9 HR }\end{array}$ & $\begin{array}{l}\text { PR vs } \\
\text { IO HR }\end{array}$ \\
\hline $\begin{array}{l}\text { Rate of mass } \\
\text { increase (g/day) }\end{array}$ & $93.56^{\mathrm{a}}$ & $80.5 \pm 6.2(10)$ & $62.3 \pm 7.1(15)$ & $66.3 \pm 8.5(15)$ & - & - & - \\
\hline Peak mass (g) & $6325 \pm 765(\mathrm{IO} 2)$ & $6578 \pm 452(10)$ & $6005 \pm 297(15)$ & $6528 \pm 406(15)$ & 1.03 & 1.60 & 1.01 \\
\hline Fledging mass (g) & $4240 \pm 576(24)$ & $5350 \pm 258(10)$ & $4303 \pm 255(15)$ & $4983 \pm 374(15)$ & $5 \cdot 57^{* *}$ & 0.38 & $4.13^{* *}$ \\
\hline Culmen length (mm) & $133.5 \pm 5.3(24)$ & $133.7 \pm 4.9(10)$ & $134.6 \pm 4.0(15)$ & $136.5 \pm 3.6(15)$ & 0.13 & 0.69 & 1.97 \\
\hline Tarsus length (mm) & $100.2 \pm 3.4(24)$ & $100.8 \pm 3.5(10)$ & $102.6 \pm 5.2(15)$ & $103.2 \pm 2.3$ (15) & 0.45 & 1.70 & $3.00^{* *}$ \\
\hline Wing length (mm) & $502 \pm 33(24)$ & $532 \pm 18(10)$ & $533 \pm 20(15)$ & $553 \pm 10(15)$ & $2.65^{*}$ & $3.27^{* *}$ & $5 \cdot 72^{* *}$ \\
\hline
\end{tabular}

${ }^{\text {a }}$ Standard deviation could not be represented because the growth rate was calculated from mean body mass weighed in each survey.

${ }^{*} \mathrm{P}<0.05$ (t-test).

$* * \mathrm{P}<0.01$ ( $t$-test $)$ 
Table 4. Blood biochemistry concentrations in parent-reared and hand-reared Short-tailed Albatross chicks, sampled just prior to fledging. Levels in parent-reared chicks $(n=30)$ were measured on Torishima Island in 2008 and those of hand-reared chicks $(n=26)$ were measured on Mukojima Island in 2008-2010. Potassium and glucose levels were not statistically compared because of unequal time between sample collection and processing at the parent-reared vs. hand-reared sites. Means $\pm \mathrm{SD}$ and range are presented.

\begin{tabular}{|c|c|c|c|c|c|}
\hline & \multicolumn{2}{|l|}{ Parent-reared } & \multicolumn{2}{|l|}{ Hand-reared } & \multirow[t]{2}{*}{$z$-statistic } \\
\hline & Means $\pm S D$ & Range & Means $\pm \mathrm{SD}$ & Range & \\
\hline Sodium $(\mathrm{mEq} / \mathrm{L})$ & $152 \pm 2$ & $148-157$ & $150 \pm 2$ & $144-155$ & $3.15^{* *}$ \\
\hline Potassium $(\mathrm{mEq} / \mathrm{L})$ & $2.5 \pm 0.6$ & $1.6-4.2$ & $4.9 \pm 0.6$ & $3 \cdot 9-6 \cdot 3$ & - \\
\hline Calcium (mg/dL) & $11.2 \pm 0.5$ & $10.2-12.1$ & $11.2 \pm 0.5$ & $9.7-11.8$ & $<0.01$ \\
\hline Phosphorus (mg/dL) & $4.0 \pm 1.4$ & $1.9-6.7$ & $4.9 \pm 0.7$ & $3 \cdot 2-6.1$ & $2.66^{* *}$ \\
\hline AST (IU/L) & $110 \pm 31$ & $83-259$ & $130 \pm 26$ & $96-222$ & $3 \cdot 97^{* *}$ \\
\hline CK (IU/L) & $637 \pm 218$ & $379-1280$ & $1254 \pm 476$ & $652-3238$ & $5 \cdot 71^{* *}$ \\
\hline Uric acid $(\mathrm{mg} / \mathrm{dL})$ & $2.7 \pm 0.8$ & $1.4-4 \cdot 5$ & $7.2 \pm 3.5$ & $2.7-16.6$ & $5 \cdot 46^{* *}$ \\
\hline Total protein $(\mathrm{g} / \mathrm{dL})$ & $4 \cdot 3 \pm 0.6$ & $4 \cdot 1-5 \cdot 3$ & $4.6 \pm 0.3$ & $4 \cdot 1-5.0$ & 1.73 \\
\hline Albumin (g/dL) & $2.2 \pm 0.3$ & $1.8-2.9$ & $2.4 \pm 0.3$ & $1.8-2.7$ & $2.88^{* *}$ \\
\hline Globulin (g/dL) & $2.1 \pm 0.5$ & $1.6-3.0$ & $2.2 \pm 0.3$ & $1.8-2.9$ & 0.56 \\
\hline Glucose (mg/dL) & $226 \pm 19$ & $189-269$ & $243 \pm 27$ & $198-293$ & - \\
\hline
\end{tabular}

AST: aspartate aminotransferase

CK: creatine kinase

${ }^{*} \mathrm{P}<0.05$ (Mann Whitney U-test).

${ }^{* *} \mathrm{P}<0.01$ (Mann Whitney $U$-test).

2009 and 2010, therefore, we selected less wary chicks on Torishima Island. In doing so, we later discovered that our translocated chick cohorts were male-biased. From these results, it appears that female Short-tailed Albatross chicks might include more individuals that react strongly to human presence and maintain a greater stress response after being handled, although some results of other studies of adult albatrosses show the opposite effect to this finding (Weimerskirch et al. 2002, de Villiers et al. 2005).

\section{Hand-feeding techniques}

It is critical to employ sterile techniques during food preparation and feeding so that seabirds are not exposed to terrestrial bacteria that are not normally encountered during their natural rearing cycle (Wingate 1972, Miskelly and Gummer 2004). Insufficient hygiene appears to have caused at least two Laysan Albatross chick deaths during the first pilot study. Hygienic procedures during food preparation and feeding should be the top priority in any hand-rearing project. In our Blackfooted Albatross and Short-tailed Albatross study, the improved sterilisation methods resulted in no chicks dying from bacterial infection. It appears, therefore, that the sterile and hygienic techniques were successful and should be followed in any future chick-rearing efforts.

Death of some Laysan Albatross chicks might have resulted from solid food given to younger chicks. Preceding studies of hand-rearing chicks of Procellariiformes recommended using pureed foods to mimic the parents' regurgitated food (Wingate 1972, Miskelly et al. 2009). Younger chicks with undeveloped digestive tracts should be given pureed food to aid digestion, even though hygiene control is more difficult. In particular, we found that pureed therapeutic pet food is the most appropriate diet for chicks during the first few days until they recover from the stress of transportation and uninitiated hand-feeding.

Muscular and skeletal growth of albatross chicks is not completed until two months after the post-guard stage (Reid et al. 2000). The Laysan Albatross chick with the injured carpal joint ligaments could not fly. This injury could have resulted from handling during feeding and measurements. In our Short-tailed Albatross studies, there were no visible outward signs of 
injury in chicks restrained with fleece blankets and placed in baskets for weighing. We recommend using this equipment and gentle procedures to restrain and handle young albatross chicks (up to three months old).

The amount and kind of foods given to chicks yielded satisfactory health and growth results; in fact, there were no notable differences in growth pattern between parent-reared and hand-reared chicks in all three species (Figures 3, 4, 5). Hand-reared Black-footed Albatross and Short-tailed Albatross chicks had similar or larger fledging body sizes than parent-reared chicks (Tables 1, 2, 3). These results also indicate the success of our feeding. Previous studies have shown greater fledging body sizes to be correlated with higher post-fledging survival and earlier first return to the natal breeding colony in seabirds without post-fledging parental care (Perrins et al. 1973, Morrison et al. 2009). However, our results should be interpreted with some caution. Male albatross chicks are larger than females (Weimerskirch et al. 2000, Hedd et al. 2002). In our study, males also had larger fledging body sizes than females in both hand-reared and parent-reared Black-footed Albatross and hand-reared Short-tailed Albatross. The sex ratios were male-biased in both handreared Black-footed Albatross and Short-tailed Albatross, but female-biased in our sample of parent-reared Black-footed Albatross, which could have influenced our results.

During the most rapid period of chick growth, parent-reared Laysan Albatross and Black-footed Albatross chicks are fed every 2-3 days, and parent-reared Short-tailed Albatross chicks are fed every day. Parents feed 3-4 times for 15-25 minutes in a single visit (Rice and Kenyon 1962, F. Sato unpubl. data). However, we chose to feed our hand-reared chicks once every day during this period to reduce handling frequency. We believe our feeding regime was appropriate because the no major problem with growth and health condition was shown in hand-reared chicks (see below).

\section{Blood chemistry}

Measurements from blood samples taken 1-2 weeks before fledging indicated that levels of phosphorus, uric acid and albumin were higher in hand-reared than parent-reared Short-tailed Albatross chicks, but except for uric acid, were still within the range of those in parent-reared chicks (Table 4). In Red Kites Milvus milvus, phosphorus level is positively correlated with alkaline phosphatase activity, which is associated with bone formation, and these parameters were elevated when the chicks were rapidly growing (Vinuela et al. 1991). Albumin represents the largest single fraction of protein in healthy individuals and serves as an energy reservoir (Hill et al. 2004). In Wedge-tailed Shearwaters Puffinus pacificus, fledglings stranded on the beach had lower albumin level than healthy chicks (Work and Rameyer 1999). In American Kestrels Falco sparverius, chicks' absolute and residual body mass was positively correlated with albumin levels (Ardia 2006). Uric acid level can be affected by dietary intake (Campbell 1986). Newman et al. (1997) found mean uric acid levels for many pelagic seabirds were between six and $30 \mathrm{mg} / \mathrm{dL}$. The uric acid levels of our hand-reared chicks were within this range (Table 4). These results suggest that hand-reared Short-tailed Albatross chicks had better growth and nutritional condition than their parent-reared counterparts.

Sodium level is used to assess osmoregulatory impairment and water intake (Seiser et al. 2000, Naidoo et al. 2008). This level was significantly lower in hand-reared than parent-reared Shorttailed Albatross chicks but the difference was very small (Table 4). When the blood samples were taken, most Short-tailed Albatross parents had already left Torishima Island and some of their chicks might become slightly dehydrated, unlike their hand-reared counterparts. Therefore, this difference should not indicate any serious health problems, such as hyponatremia, in hand-reared chicks.

The blood levels of AST and CK were higher in hand-reared than parent-reared Short-tailed Albatross chicks (Table 4). Muscle cells are one of the primary tissues containing these enzymes, and elevated levels in the blood can indicate muscle damage (Hochleithner 1994). These high levels in hand-reared chicks would indicate that our handling techniques, such as daily capture for 
feeding, probably cause some damage to the muscles (Bollinger et al. 1989, Nicolson et al. 2000, Guglielmo et al. 2001). Capture and handling techniques at feeding need to be further improved beyond what we achieved in our study because high elevated levels of AST and CK are important signs of a potentially life threatening syndrome, capture myopathy (Bollinger et al. 1989, Nicolson et al. 2000).

\section{Predicting the study outcome}

We do not know the fate of hand-reared Laysan Albatross fledglings: there has been little effort made to resight returning birds, and none have been documented. However, in 2010, we did confirm the return to Mukojima of three Black-footed Albatrosses hand-reared in 2007. In 2011, six Short-tailed Albatrosses hand-reared in 2008 and one from the 2009 cohort were observed at the release site on Mukojima Island (T. Deguchi unpubl. data). These return rates by young age classes appear equal to or greater than what has been observed for parent-reared Black-footed Albatross and Short-tailed Albatross (Rice and Kenyon 1962, F. Sato unpubl. data). Returning individuals of both species looked and behaved normally, and both species engaged in apparently normal courtship dances at the release site. This strongly suggests that translocated birds were successfully habitat- and species-imprinted, having avoided becoming sexually imprinted on humans, as warned by Wallace (1994).

Miskelly et al. (2009) suggest that the combination of sound attraction and chick translocation are effective methods for the establishment of new petrel colonies. In 2009 and 2010 when the vocalisation playback unit was operational, we observed at least three different subadult Shorttailed Albatrosses (identified by plumage patterns), that had not been hand-reared, at the release site on Mukojima Island during the hand-rearing period (T. Deguchi unpubl. data). We believe these birds were attracted to decoys and translocated chicks because they approached and interacted with them. As the Short-tailed Albatross population on Torishima Island continues its steady growth (Hasegawa 2007), the number of Short-tailed Albatrosses prospecting other islands in the region, including the translocation site, should increase in the future. Our study will involve two more years of hand-feeding and several checks for returning birds. Once returning translocated birds actually begin to breed on Mukojima Island, our efforts will be considered fully successful.

We successfully developed techniques and demonstrated the feasibility of translocating and hand-rearing albatrosses. These techniques provide a potentially viable management action, should human intervention be required to re-establish extirpated breeding colonies, establish colonies on islands free of introduced predators, or at higher elevations to guard against potential losses from sea level rise.

\section{Supplementary Material}

The supplementary materials for this article can be found at journals.cambridge.org/bci

\section{Acknowledgements}

We thank H. Hasegawa, T. Smith, S. Yamagishi, Y. Hayashi, H. Shimazu, F. Akishinonomiya for their invaluable support, without which this study would not have been possible. We also thank T. Arai, T. Baba, B. Call, N. Chikira, N. Emura, Y. Harada, T. Hiraoka, T. Kaneko, M. Konno, S. Konno, S, Kudo, Y. Kunita, R. Nakayama, Y. Niizuma, S. Numata, J. Obata, K. Saitoh, K. Shimada, Y, Shitara, P. Sievert, S. Sims, C. Sterne, Y. Suda, R. Suryan, H. Suzuki, K. Suzuki, I. Takahashi, M. Takenaga, M. Watanabe, T. Work, T. Yanagawa, K. Yoshida, L. Young, T. Yuta, B. Zaun for their assistance in conducting field and laboratory work, and in providing logistical support on the islands. We also thank R. Suryan for valuable comments on the manuscript. This project was 
supported by grants-in-aid and donations from US Fish and Wildlife Service, US National Fish and Wildlife Foundation, Japan Ministry of Environment, Japan Ministry of Education, Culture, Sports, Science and Technology, Suntory Fund for Birds Conservation, Asahi Newspaper Company, Mitsui \& Co., Ltd. Environmental Fund, North Pacific Research Board (\#309) and the Yamashina Special Support Group.

\section{References}

Ardia, D. R. (2006) Glycated hemoglobin and albumin reflect nestling growth and condition in American kestrels. Comp. Biochem. Physiol. A 143: 62-66.

Austin, O. L. (1949) The status of Steller's albatross. Pacific Sci. 3: 283-295.

Baker, G. B., Gales, R., Hamilton, S. and Wilkinson, V. (2002) Albatrosses and petrels in Australia: a review of their conservation and management. Emu 102: 71-97.

Baker, J. D., Littnan, C. L. and Johnston, D. W. (2006) Potential effects of sea level rise on the terrestrial habitats of endangered and endemic megafauna in the northwestern Hawaiian Islands. Endang. Species Res. 4: 1-10.

Bollinger, T., Wobeser, G., Clark, R. G., Nieman, D. J. and Smith, J. R. (1989) Concentration of creatine kinase and aspartate aminotransferase in the blood of wild Mallards following capture by three methods for banding. J. Wildl. Dis. 25: 225-231.

Campbell, T. W. (1986) Avian clinical hematology and blood chemistry. Pp. 264-276 in E. H. Coles, ed. Veterinary clinical pathology. Philadelphia: W. B. Saunders Company.

Carlile, N., Priddel, D. and Madeiros, J. (2012) Establishment of a new, secure colony of Endangered Bermuda Petrel Pterodroma cahow by translocation of nearfledged nestlings. Bird Conserv. Internatn. 22: $46-58$.

Croxall, J. P., Butchart, S. H. M., Lascelles, B., Stattersfield, A. J., Sullivan, B., Symes, A. and Taylor, P. (2012) Seabird conservation status, threats and priority actions: a global assessment. Bird Conserv. Internatn. 22: 1-34.

de Villiers, M. S., Cooper, J. and Ryan, P. G. (2005) Individual variability of behavioural responses by wandering albatrosses (Diomeda exulans) to human disturbance. Pol. Biol. 28: 255-26o.

Fisher, H. I. (1967) Body weight in Laysan Albatross Diomedea immutabilis. Ibis 1o9: $373-382$.
Fisher, H. I. (1971) Experiments on homing in Laysan Albatross, Diomeda immutabilis. Condor 73: 389-400.

Gulglielmo, C. G., Piersma, T. and Williams, T. D. (2001) A sport-physiological perspective on bird migration: evidence for flightinduced muscle damage. J. Exp. Biol. 204: 2683-269o.

Gummer, H. (2003) Chick translocation as a method of establishing new surfacenesting seabird colonies: a review. Wellington, New Zealand: Department of Conservation.

Harada, T., Deguchi, T., Zaun, B., Sprague, R. S. and Jacobs, J. (2008) An artificial rearing experiments of Laysan Albatross chicks. J. Yamashina Inst. Ornithol. 39: 87-100.

Hasegawa, H. (2003) Toward a full recovery of Short-tailed Albatross: from 50 to 5000 birds. Tokyo: Doubutsu-Sha.

Hasegawa, H. (2007) Conservation of large seabird, Short-tailed Albatross. Pp. 89-104 in S. Yamagishi and Yamashina Institute for Ornithology, eds. Conservation ornithology. Kyoto, Japan: Kyoto University Press.

Hedd, A., Gales, R. and Brothers, N. (2002) Provisioning and growth rates of shy albatrosses at Albatross Island, Tasmania. Condor 104: 12-29.

Hill, R., Wyse, G. and Anderson, M. (2004) Animal physiology. Sunderland, MA: Sinauer.

Hilton, G. M. and Cuthbert, R. J. (2010) The catastrophic impact of invasive mammalian predators on birds of the UK Overseas Territories: a review and synthesis. Ibis 152: $443-458$.

Hochleithner, M. (1994) Biochemistries. Pp. 233-245 in B. W. Ritchie, G. J. Harrison, and L. R. Harrison, eds. Avian medicine: Principles and application. Lake Worth, FL: Winger Press.

Howell, T. R. and Bartholomew, G. A. (1961) Temperature regulation in Laysan and Blackfooted Albatrosses. Condor 63: 185-197. 
Madeiros, J., Priddel, D. and Carlile, N. (2012) Breeding biology and population increase of the Endangered Bermuda Petrel Pterodroma cahow. Bird Conserv. Internatn. 22: $35-45$.

Marchant, S. and Higgins, P. J. (1990) Handbook of Australian, New Zealand \& Antarctic birds. Melbourne, Australia: Oxford University Press.

Meyer, L., Constable, A. and Williams, R. (2000) Conservation of marine habitats in the region of Heard Island and McDonald Island. Kingston, Australia: Australian Antarctic Division.

Miskelly, C. M. and Gummer, H. (2004) Third and final transfer of fairly prion (titiwainui) chicks from Takapourewa to Mana island. Wellington, New Zealand: Department of Conservation.

Miskelly, C. M., Taylor, G. A., Gummer, H. and Williams, R. (2009) Translocation of eight species of burrow-nesting seabirds (genera Pterodroma, Pelecanoides, Pachyptila and Puffinus: Family Procellariidae). Biol. Conserv. 142: 1965-1980.

Morrison, K. W., Hipfner, J. M., Gjerdrum, C. and Green, D. J. (2009) Wing length and mass at fledging predict local juvenile survival and age at first return in tufted puffins. Condor 111: 433-441.

Naidoo, V., Diekmann, M., Wolters, K. and Swan, G. E. (2008) Establishment of selected baseline blood chemistry and hematologic parameters in captive and wild-caught African white-backed vultures (Gyps africans). J. Wildl. Dis. 44: 649-654.

Nanji, A. A. (1984) Misleading biochemical laboratory test results. Can. Med. Assoc. J. 130: 1435-1441.

Newman, S. H., Piatt, J. F. and White, J. (1997) Hematological and plasma reference ranges of Alaskan seabirds: their ecological significance and clinical importance. Colon. Waterbirds 20: 492-504.

Nicolson, D. S., Lochmiller, R. L., Stewart, M. D., Masters, R. E. and Leslie, D. M. Jr. (2000) Risk factors associated with capturerelated death in eastern wild turkey hens. J. Wildl. Dis. 36: 308-315.

Perrins, C., Harris, M. P. and Britton, C. K. (1973) Survival of Manx shearwater Puffinus puffinus. Ibis 115: 535-548.
Priddel, D., Carlile, N. and Wheeler, R. (2006) Establishment of a new breeding colony of Gould's petrel (Pterodroma leucoptera leucoptera) through the creation of artificial nesting habitat and the translocation of nestlings. Biol. Conserv. 128: 553-563.

Regnier, J. A. and Kelley, K. W. (1981) Heatand cold-stress suppresses in vivo and in vitro cellular immune responses of chickens. Am. J. Vet. Res. 42: 294-299.

Reid, K., Prince, P. A. and Croxall, J. P. (200o) Fly or die: the role of fat stores in the growth and development of grey-headed albatross Diomedea chrysostoma chicks. Ibis 142: 188-198.

Rice, D. W. and Kenyon, K. W. (1962) Breeding cycles and behavior of Laysan and Blackfooted Albatrosses. Auk 79: 517-567.

Ricklefs, R. E. (1968) Patterns of growth in birds. Ibis 110: 419-451.

Robertson, C. J. R. (2001) Effects of intervention on the Royal albatross population at Taiaroa Head, Otago, 1937-2001. Wellington, New Zealand: Department of Conservation.

Robertson, C. J. R. and Wright, A. (1973) Successful hand-rearing of an abandoned royal albatross chick. Notornis 20: 49-58.

Seiser, P. E., Duffy, L. K., McGuire, A. D., Roby, D. D., Golet, G. H. and Litzow, M. A. (2000) Comparison of Pigeon guillemot, Cepphus columba, blood parameters from oiled and unoiled areas of Alaska eight years after the Exxon Valdez oil spill. Mar. Poll. Bull. 40: 152-164.

Siegel, H. S. (1985) Immunological responses as indicators of stress. World's Poult. Sci. J. 41: $36-44$.

Teixeira, C. P., de Azevedo, C. S., Mendl, M., Cipreste, C. F. and Young, R. J. (2007) Revisiting translocation and reintroduction programmes: the importance of considering stress. Anim. Behav. 73: 1-13.

Tickell, W. L. N. (2000) Albatrosses. Sussex, UK: Pica Press.

Torishima Society (1967) Torishima. Tokyo: Toko-Shoin.

USFWS (2008) Short-tailed Albatross recovery plan. Anchorage, Alaska: US Fish and Wildlife Service.

Vinuela, J., Ferrer, M. and Recio, F. (1991) Age-related variations in plasma levels of 
alkaline phosphatase, calcium and inorganic phosphorus in chicks of two species of raptors. Comp. Biochem. Physiopl A 99: 49-54.

Wallace, M. P. (1994) Control of behavioral development in the context of reintroduction programs for birds. Zoo Biol. 13: 491-499.

Watabe, E. (1963) The albatross on Torishima. Pp. 156-168 in Meteorological data and report of Marcus and Torishima Islands. Tokyo: Meteorological Agency of Japan.

Weather Underground (2010) History for north shore of Kauai, Princeville, HI. Accessed on 10 March 2011 at http:// www.wunderground.com/weatherstation/ WXDailyHistory.asp? ID =KHIPRINC 1 .

Weimerskirch, H., Barbaraud, C. and Patrice, L. (2000) Sex differences in parental investment and chick growth in wandering albatrosses: fitness consequences. Ecology 81: 309-318.

Weimerskirch, H., Shaffer, S. A., Mabille, G., Martin, J., Boutard, O. and Rouanet, J. J. (2002) Heart rate and energy expenditure of incubation wandering albatrosses: basal levels, natural variation, and the effects of human disturbance. J. Exp. Biol. 205: 475-483.

Wingate, D. B. (1972) First successful handrearing of an abandoned Bermuda petrel chick. Ibis 114: 97-101.

Whittow, G. C. (1993a) Black-footed albatross (Diomedea nigripes). Pp. $1-16$ in A. Poole and F. Gill, eds. The birds of North America, No. 65. Washington DC: The Academy of Natural Science and The American Ornithologists' Union.

Whittow, G. C. (1993b) Laysan albatross (Diomedea immutabilis). Pp. $1-20$ in A. Poole and F. Gill, eds. The birds of North America, No. 66. Washington DC: The Academy of Natural Science and The American Ornithologists' Union.

Work, T. M. and Rameyer, R. A. (1999) Mass stranding of wedge-tailed shearwater chicks in Hawaii. J. Wildl. Dis 35: 487-495.

Yamamoto, S. (1954) Short-tailed Albatross on Torishima. Bull. Central Meteorol. Observatory 21: 232-233.

Yamashina, Y. (1942) Birds of the seven islands of Izu. Tori 11: 191-270.

\section{TOMOHIRO DEGUCHI*, FUMIO SATO, NOBORU NAKAMURA, KIYOAKI OZAKI}

Division of Avian Conservation, Yamashina Institute for Ornithology, 115 Konoyama, Abiko 270-1145, Japan.

\section{JUDY JACOBS, GREG BALOGH}

Anchorage Field Office Endangered Species Program, U.S. Fish \& Wildlife Service, 1011 East Tudor Rd., Anchorage, AK 99503, USA.

\section{TOMOKO HARADA}

Laboratory of Marine Ecology, Graduate School of Fisheries Science, Hokkaido University, 3-1-1 Minato-cho, Hakodate 041-8611, Japan.

\section{LYNDON PERRIMAN}

Coastal Otago Area Office, Department of Conservation, 77 Stuart Street, Dunedin, New Zealand.

\section{YUKI WATANABE}

Akan International Crane Center, 23-40 Akan-cho, Kushiro 085-0245, Japan.

*Author for correspondence; e-mail: deguchi@yamashina.or.jp

Received 10 March 2011; revision accepted I June 2011; Published online 16 December 2011 